UDC 29.19.04, 29.19.21

\author{
Zh. Karipbaev ${ }^{1}$, D. Musakhanov ${ }^{1,2}$, V. Lisitsyn ${ }^{2}$, G. Alpyssova ${ }^{1}$, \\ M. Golkovskii ${ }^{3}$, L. Lisitsyna ${ }^{4}$, A. Tulegenova ${ }^{5}$, A. Akylbekov ${ }^{1}$, \\ A. Dauletbekova ${ }^{1}$, K. Balabekov ${ }^{1}$, A. Kozlovskii ${ }^{6}$, A. Usseinov ${ }^{1}$ \\ ${ }^{1}$ L.N. Gumilyov Eurasian National University, Nur-Sultan, Kazakhstan; \\ ${ }^{2}$ Tomsk Politechnical University, Russia; \\ ${ }^{3}$ Scientific Research Institute of Nuclear Physics SB RAS, Novosibirsk, Russia; \\ ${ }^{4}$ Tomsk State University, Russia; \\ ${ }^{5}$ Al-Farabi Kazakh National University, Almaty, Kazakhstan; \\ ${ }^{6}$ Institute of Nuclear Physics, Nur-Sultan, Kazakhstan \\ (E-mail:zf1@mail.ru)
}

\title{
Synthesis, the study of the structure of YAG and YAGG phosphors in the radiation field
}

\begin{abstract}
In the present work, an attempt is made to synthesize a phosphor using powerful hard radiation fluxes. The surface, elemental composition, structure, and luminescent characteristics of the obtained YAG:Ce ceramics were studied. Ceramics have a heterogeneous structure. The main phase of the obtained ceramics is YAG, which ranges from 72 to $91 \%$ of the total volume of samples. The remaining volume of the samples consists of the $\mathrm{Al}_{2} \mathrm{O}_{3}$ and $\mathrm{CeO}_{2}$ phases. The synthesized ceramics has the characteristic properties of YAG:Ce, YAGG:Ce phosphors. The surface condition and elemental surface composition of the synthesized ceramic sample were studied using a scanning electron microscope. The images showed that there are particles with a well-defined faceting, which indicates the formation of microcrystals. X-ray diffraction analysis of the synthesized ceramic samples was carried out on a diffractometer. X-ray diffraction analysis showed that the resulting ceramic has a high degree of crystallinity. The quantitative phase dependence was determined in the TOPAS-4.2 program. The results of measuring the luminescence spectra measured upon excitation of the specimen split surface are presented. The maximum luminescence of YAG:Ce ceramics accounts for $555 \mathrm{~nm}$, the half-width of the band is $0.45 \mathrm{eV}$. In YAGG:Ce ceramics, the luminescence maximum at $555 \mathrm{~nm}$, the half-width of the band is $0.48 \mathrm{eV}$.
\end{abstract}

Keywords: white LEDs, yttrium-aluminum garnet, phosphor, ceramics, synthesis in the radiation field.

\section{Introduction}

White light-emitting diodes (LEDs) are considered a good lighting devices due to their unsurpassed qualities, such as energy saving and long service life $[1,2]$. In the most common LEDs, the blue radiation of the chip is converted into yellow by the phosphor. The combination of blue chip radiation and yellow phosphor gives white light. As phosphors, microcrystalline powders of yttrium-aluminum garnet (YAG:Ce), activated with cerium, are most often used [2-4].

YAG: $\mathrm{Ce}^{3+}$ phosphor emits in the range of $500-700 \mathrm{~nm}$, the luminescence maximum is $550 \mathrm{~nm}$ [5]. The quantum efficiency of YAG: $\mathrm{Ce}^{3+}$ phosphor radiation can reach $85 \%$ [6].

YAG:Ce phosphor is most often synthesized from metal oxides under extreme conditions: thorough mixing of the initial powders, high temperatures during sintering, crushing to the desired size, annealing at high temperatures. The reproducibility of the synthesis with this technology is clearly insufficient. Therefore, other methods are being developed: sol-gel method [7], combustion method [8], coprecipitation [9] and others. But all the methods of synthesis still end with high-temperature annealing. In the practice of industrial synthesis is dominated the method of solid-state reaction as the cheapest.

In recent years, radiation methods for modifying, synthesizing films and even ceramics have been developed $[10,11]$. In this paper, it was attempted phosphor synthesis using powerful hard radiation fluxes. The surface, elemental composition, structure and luminescent characteristics of obtained YAG:Ce ceramics were studied.

\section{Objects and research methods}

YAG:Ce and YAGG:Ce ceramics samples were synthesized in the radiation field. For the synthesis, a mixture from a powders mixture of $\mathrm{Al}_{2} \mathrm{O}_{3}, \mathrm{Y}_{2} \mathrm{O}_{3}, \mathrm{Gd}_{2} \mathrm{O}_{3}$, and $\mathrm{Ce}_{2} \mathrm{O}_{3}$ oxides brands ch.c was prepared. The ratio of oxides in the charge was equal to stoichiometric. With cerium dopping for activation and gadolinium 
for modification, the ratio of the initial compositions was adjusted. It was supposed that the activator and modifier ions enter the lattice by replacing yttrium ions. The oxide powders had particles form of irregular shape with dimensions of about 1 micron and less. In a liquid medium, the particles are trying to combine into complexes. The charge was poured into a copper melting pot with a layer $5 \mathrm{~mm}$. A flux of electrons with an energy of $1.4 \mathrm{MeV}$ from the ELV-6 accelerator with an average power of $23 \mathrm{~kW} / \mathrm{cm}^{2}$ was directed to the melting pot with the charge. The beam section of a Gaussian shape at half-height was $0.7 \mathrm{~cm}^{2}$. The beam scanned on the surface of the melting pot at a speed of $1 \mathrm{~cm} / \mathrm{s}$. All surface processing of the melting pot was $25 \mathrm{~s}$. As a result of processing, ceramic samples were formed in the melting pot in the form of droplets with sizes up to $0.5 \times 1.0 \times 2.0 \mathrm{~cm}$. The samples had a high hardness close to sapphire. The split plane had a characteristic for ceramics form with a rough surface. YAG:Ce ceramics samples had a light yellow color like a YAG:Ce and dark yellow-YAGG:Ce.

The state of the surface and the elemental composition of synthesized ceramics samples surface were studied using Hitachi TM-scanning electron microscope (SEM) 3030 with the Bruker XFlash MIN SVE energy dispersive analysis system at an accelerating voltage of $15 \mathrm{kV}$. X-ray diffraction analysis of synthesized ceramic samples was performed on a D8 ADVANCE ECO diffractometer with an X-ray tube with a copper anode and a graphite monochromator. Diffraction patterns were recorded in the range of angles $\left(20-110^{\circ}\right)$ $2 \theta$ with a step of $0.022 \theta$. Quantitative phase dependence was determined in the TOPAS-4.2 program. The half-width of the measured reflections was used to determine the sizes of crystallites and microstresses in the sample. The ratio of the integral intensity of reflections to the total intensity of x-rays was used to evaluate the degree of crystallinity of the sample.

\section{SEM images and elemental analysis of phosphors}

The morphology, elemental composition, structure ofobtained samples were investigated. In the chips SEM images it can be seen that the ceramic samples are soldered to each other particles with sizes of $\sim 5$...50 microns (Fig. 1). Most particles have a melt appearance. There are particles with a well-defined cut, which indicates about microcrystals formation.
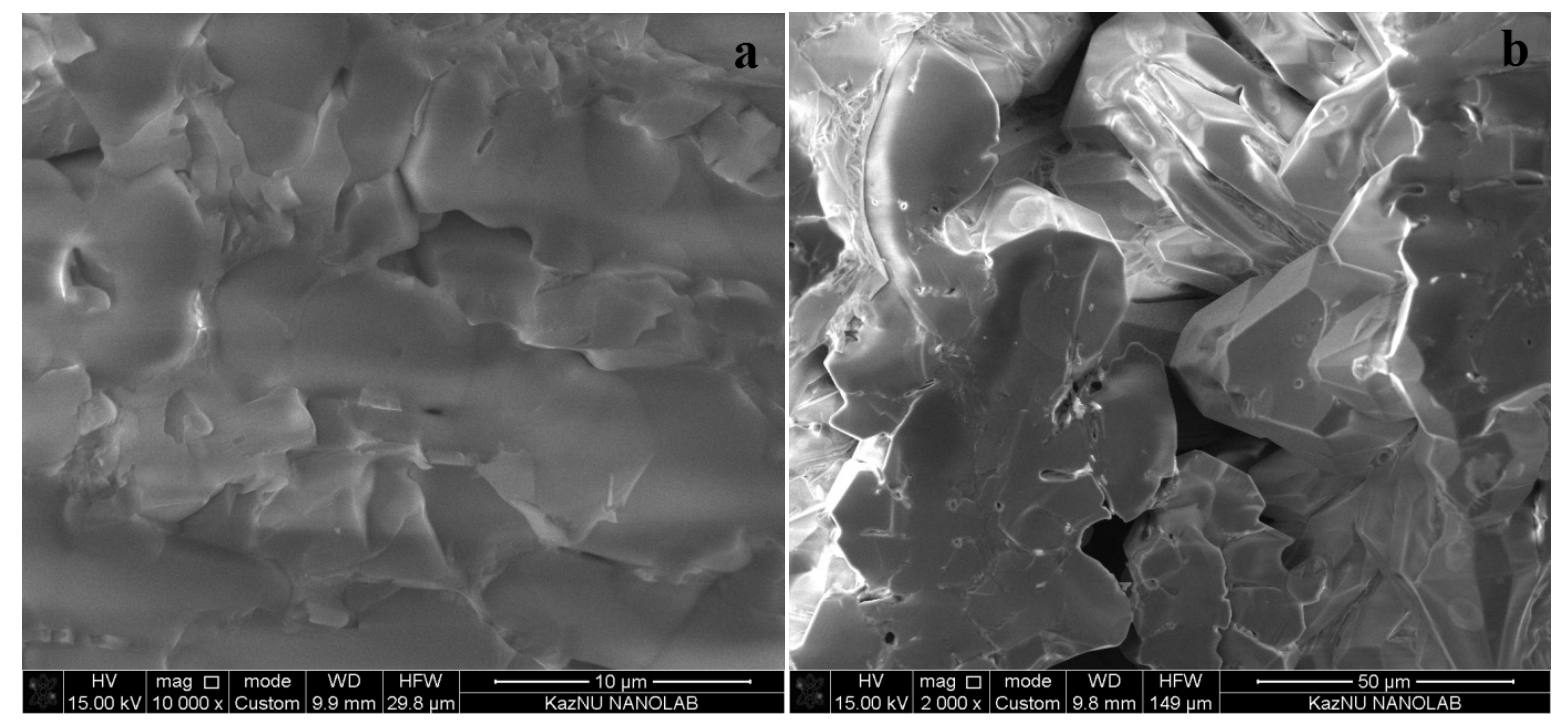

$$
a-\mathrm{YAG}: \mathrm{Ce} ; b-\mathrm{YAGG}: \mathrm{Ce}
$$

Figure 1. The morphology of synthesized ceramics in a radiation field

The elemental composition of obtained YAG:Ce, YAGG: Ce samples differ from initial composition in charge. The proportion of aluminum ions exceeded the charge during the charge formation relative to $\mathrm{Y}, \mathrm{Ce}$, Gd. Therefore, the resulting ceramics has a non-stoichiometric composition (Tables 1,2). 
The elemental composition of the surface of obtained samples of ceramics

\begin{tabular}{|c|c|c|c|c|}
\hline $\begin{array}{c}\text { Atom } \\
\text { (at.\%) }\end{array}$ & $\begin{array}{c}\mathrm{Al}_{2} \mathrm{O}_{3}(56,8 \%)+ \\
\mathrm{Y}_{2} \mathrm{O}_{3}(34,1 \%)+ \\
\mathrm{Ce}_{2} \mathrm{O}_{3}(9,1 \%) \\
(22 \mathrm{KBT})\end{array}$ & $\begin{array}{c}\mathrm{Al}_{2} \mathrm{O}_{3}(59,5 \%)+ \\
\mathrm{Y}_{2} \mathrm{O}_{3}(35,7 \%)+\end{array}$ & $\begin{array}{c}\mathrm{Al}_{2} \mathrm{O}_{3}(56,8 \%)+ \\
\mathrm{Ye}_{2} \mathrm{O}_{3}(22,7 \%)+ \\
\mathrm{Gd}_{2} \mathrm{O}_{3}(11,4 \%)+ \\
\mathrm{Ce}_{2} \mathrm{O}_{3}(9,1 \%)(22 \%)\end{array}$ & $\begin{array}{c}\mathrm{Al}_{2} \mathrm{O}_{3}(59,5 \%)+ \\
\mathrm{Y}_{2} \mathrm{O}_{3}(23,8 \%)+ \\
\mathrm{Gd}_{2} \mathrm{O}_{3}(11,9 \%)+ \\
\mathrm{Ce}_{2} \mathrm{O}_{3}(4,8 \%)\left(25 \mathrm{KBT}^{2}\right)\end{array}$ \\
\hline $\mathrm{O}$ & 65.84 & 62.74 & 69.58 & 57.51 \\
\hline $\mathrm{Al}$ & 26.16 & 33.02 & 28.72 & 36.36 \\
\hline $\mathrm{Y}$ & 7.23 & 3.66 & 0.93 & 4.15 \\
\hline $\mathrm{Ce}$ & 0.77 & 0.53 & 0.63 & 0.71 \\
\hline $\mathrm{Gd}$ & - & 0.06 & 0.15 & 1.26 \\
\hline
\end{tabular}

Table 2

The elemental composition of the crushed phosphor

\begin{tabular}{|c|c|c|c|}
\hline $\begin{array}{c}\text { Atom } \\
(\text { at. })\end{array}$ & $\begin{array}{c}\mathrm{Al}_{2} \mathrm{O}_{3}(56,8 \%)+\mathrm{Y}_{2} \mathrm{O}_{3}(34,1 \%)+ \\
\mathrm{Ce}_{2} \mathrm{O}_{3}(9,1 \%)(22 \mathrm{KBT})\end{array}$ & $\begin{array}{c}\mathrm{Al}_{2} \mathrm{O}_{3}(56,8 \%)+\mathrm{Y}_{2} \mathrm{O}_{3}(22,7 \%)+ \\
\mathrm{Gd}_{2} \mathrm{O}_{3}(11,4 \%)+\mathrm{Ce}_{2} \mathrm{O}_{3}(9,1 \%) \\
(22 \mathrm{KBT})\end{array}$ & $\begin{array}{c}\mathrm{Al}_{2} \mathrm{O}_{3}(56,8 \%)+\mathrm{Y}_{2} \mathrm{O}_{3}(34,1 \%)+ \\
\mathrm{Ce}_{2} \mathrm{O}_{3}(9,1 \%)(25 \mathrm{KBT})\end{array}$ \\
\hline $\mathrm{O}$ & 57.39 & 52.81 & 66.32 \\
\hline $\mathrm{Al}$ & 33.26 & 37.76 & 25.65 \\
\hline $\mathrm{Y}$ & 7.55 & 7.29 & 7.49 \\
\hline $\mathrm{Ce}$ & 1.8 & 1.35 & 0.54 \\
\hline $\mathrm{Gd}$ & - & 0.8 & - \\
\hline
\end{tabular}

X-ray structural analysis showed that the resulting ceramics has a high degree of crystallinity, about $80 \%$ (Fig. 2). The basis of YAG ceramics is made up of crystals with a size of $47 \mathrm{~nm}$, YAGG - $81 \mathrm{~nm}$. The existence of a separate phase of corundum was found in ceramics. The lattice parameters of YAG, YAGG, and $\mathrm{Al}_{2} \mathrm{O}_{3}$ are close to those known for crystals: $a, b, \approx 12.023$ in YAG, 12.055 in YAGG, 4.75 in $\mathrm{Al}_{2} \mathrm{O}_{3}\left(\mathrm{Table}_{3}\right)$.

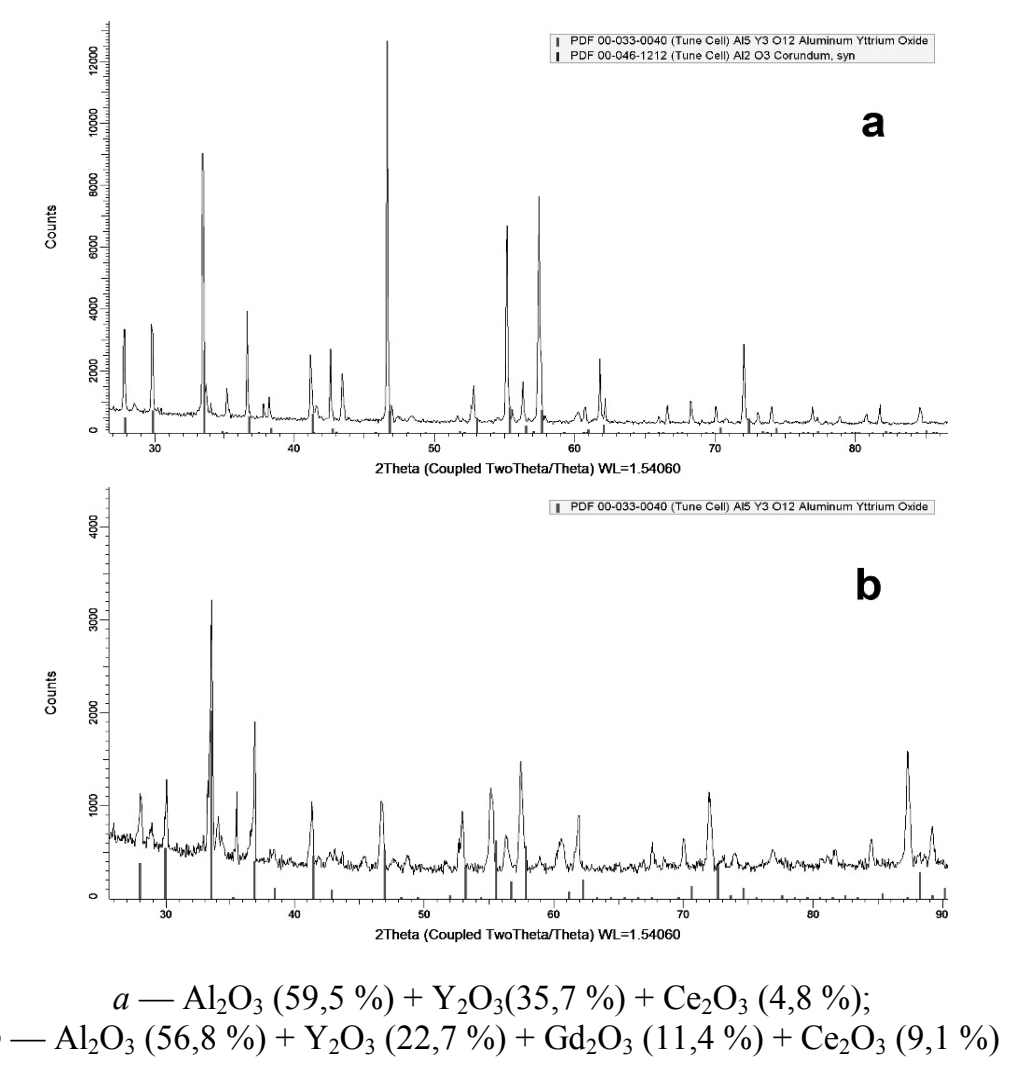

Figure 2. Diffractograms of the investigated samples 
Table 3

Results of X-ray diffraction analysis of synthesized ceramics

\begin{tabular}{|c|c|c|c|c|c|}
\hline Initialcomposition & Phase & $\begin{array}{c}\text { Lattice } \\
\text { parameters, } \AA\end{array}$ & $\begin{array}{c}\text { Crystallite size, } \\
\text { nm }\end{array}$ & \begin{tabular}{|c|}
$\begin{array}{c}\text { Crystalline } \\
\text { degree, } \%\end{array}$ \\
\end{tabular} & $\begin{array}{c}\text { Phase contain, } \\
\% \\
\end{array}$ \\
\hline \multirow{2}{*}{$\begin{array}{c}\mathrm{Al}_{2} \mathrm{O}_{3}(59,5 \%)+ \\
\mathrm{Y}_{2} \mathrm{O}_{3}(35,7 \%)+ \\
\mathrm{Ce}_{2} \mathrm{O}_{3}(4,8 \%) \\
(22 \mathrm{KBT}, 12.04 .2018)\end{array}$} & $\begin{array}{l}\mathrm{Al}_{2} \mathrm{Y}_{3} \mathrm{O}_{12}-\mathrm{Cubic} \\
\quad \mathrm{Ia}-3 \mathrm{~d}(230)\end{array}$ & $a=11.98300$ & 64.5 & \multirow{2}{*}{91.0} & 71.7 \\
\hline & $\begin{array}{c}\mathrm{Al}_{2} \mathrm{O}_{3}-\text { Rhombo.H.axes - } \\
\text { R-3c(167) }\end{array}$ & $\begin{array}{l}a=4.74657 \\
c=13.01621\end{array}$ & 61.5 & & 28.3 \\
\hline \multirow{3}{*}{$\begin{array}{c}\mathrm{Al}_{2} \mathrm{O}_{3}(56,8 \%)+ \\
\mathrm{Y}_{2} \mathrm{O}_{3}(34,1 \%)+ \\
\mathrm{Ce}_{2} \mathrm{O}_{3}(9,1 \%) \\
(22 \mathrm{KBT}, 11.04 .2018)\end{array}$} & $\begin{array}{l}\mathrm{Al}_{2} \mathrm{Y}_{3} \mathrm{O}_{12}-\text { Cubic } \\
\text { Ia-3d(230) }\end{array}$ & $a=11.96366$ & 48.3 & \multirow{3}{*}{91.1} & 82.4 \\
\hline & $\begin{array}{c}\mathrm{Al}_{2} \mathrm{O}_{3}-\text { Rhombo.H.axes - } \\
\text { R-3c(167) }\end{array}$ & $\begin{array}{l}a=4.80604 \\
c=13.04118\end{array}$ & 44.7 & & 14.9 \\
\hline & $\mathrm{CeO}_{2}-$ Cubic Fm-3m(225) & $a=5.53065$ & 51.7 & & 2.6 \\
\hline \multirow{2}{*}{$\begin{array}{c}\mathrm{Al}_{2} \mathrm{O}_{3}(59,5 \%)+ \\
\mathrm{Y}_{2} \mathrm{O}_{3}(23,8 \%)+ \\
\mathrm{Gd}_{2} \mathrm{O}_{3}(11,9 \%)+ \\
\mathrm{Ce}_{2} \mathrm{O}_{3}(4,8 \%) \\
(25 \mathrm{KBT}, 11.04 .2018)\end{array}$} & $\begin{array}{l}\mathrm{Al}_{2} \mathrm{Y}_{3} \mathrm{O}_{12}-\mathrm{Cubic} \\
\quad \mathrm{Ia}-3 \mathrm{~d}(230) \\
\end{array}$ & $a=11.95920$ & 28.7 & \multirow[b]{2}{*}{88.1} & 83.0 \\
\hline & $\begin{array}{c}\mathrm{Al}_{2} \mathrm{O}_{3}-\text { Rhombo.H.axes - } \\
\text { R-3c(167) }\end{array}$ & $\begin{array}{l}a=4.72784 \\
c=12.93445\end{array}$ & 42.9 & & 17.0 \\
\hline \multirow{2}{*}{$\begin{array}{c}\mathrm{Al}_{2} \mathrm{O}_{3}(56,8 \%)+ \\
\mathrm{Y}_{2} \mathrm{O}_{3}(34,1 \%)+ \\
\mathrm{Ce}_{2} \mathrm{O}_{3}(9,1 \%) \\
(22 \mathrm{KBT}, 11.04 .2018)\end{array}$} & $\begin{array}{c}\mathrm{Al}_{2} \mathrm{Y}_{3} \mathrm{O}_{12}-\text { Cubic } \\
\text { Ia-3d(230) } \\
\end{array}$ & $a=12.01313$ & 46.1 & \multirow{2}{*}{86.3} & 91.2 \\
\hline & $\begin{aligned} & \mathrm{Al}_{2} \mathrm{O}_{3}- \text { Rhombo.H.axes - } \\
& \text { R-3c(167) }\end{aligned}$ & $\begin{array}{l}a=4.76400 \\
c=12.99785\end{array}$ & 44.4 & & 8.8 \\
\hline \multirow{3}{*}{$\begin{array}{c}\mathrm{Al}_{2} \mathrm{O}_{3}(56,8 \%)+ \\
\mathrm{Y}_{2} \mathrm{O}_{3}(34,1 \%)+ \\
\mathrm{Ce}_{2} \mathrm{O}_{3}(9,1 \%) \\
(22 \mathrm{KBT}, 12.04 .2018)\end{array}$} & $\begin{array}{l}\mathrm{Al}_{2} \mathrm{Y}_{3} \mathrm{O}_{12}-\mathrm{Cubic} \\
\quad \mathrm{Ia}-3 \mathrm{~d}(230)\end{array}$ & $a=11.94255$ & 47.4 & \multirow{3}{*}{92.4} & 82.3 \\
\hline & $\begin{array}{c}\mathrm{Al}_{2} \mathrm{O}_{3}-\text { Rhombo.H.axes - } \\
\text { R-3c(167) }\end{array}$ & $\begin{array}{l}a=4.79379 \\
c=13.11022\end{array}$ & 44.7 & & 2.0 \\
\hline & $\mathrm{CeO}_{2}-$ Cubic Fm-3m(225) & $a=5.52306$ & 50.6 & & 15.7 \\
\hline \multirow{3}{*}{$\begin{array}{c}\mathrm{Al}_{2} \mathrm{O}_{3}(56,8 \%)+ \\
\mathrm{Y}_{2} \mathrm{O}_{3}(22,7 \%)+ \\
\mathrm{Gd}_{2} \mathrm{O}_{3}(11,4 \%)+ \\
\mathrm{Ce}_{2} \mathrm{O}_{3}(9,1 \%) \\
(22 \mathrm{KBT}, 11.04 .2018)\end{array}$} & $\begin{array}{c}\mathrm{Al}_{2} \mathrm{Y}_{3} \mathrm{O}_{12}-\mathrm{Cubic} \\
\mathrm{Ia}-3 \mathrm{~d}(230)\end{array}$ & $a=11.96328$ & 71.5 & \multirow{3}{*}{89.8} & 73.6 \\
\hline & $\begin{array}{c}\mathrm{Al}_{2} \mathrm{O}_{3}-\text { Rhombo.H.axes - } \\
\text { R-3c(167) }\end{array}$ & $\begin{array}{l}a=4.79285 \\
c=13.07166\end{array}$ & 98.2 & & 1.7 \\
\hline & $\mathrm{CeO}_{2}-$ Cubic Fm-3m(225) & $a=5.50465$ & 81.7 & & 24.6 \\
\hline $\begin{array}{c}\mathrm{Al}_{2} \mathrm{O}_{3}(56,8 \%)+ \\
\mathrm{Y}_{2} \mathrm{O}_{3}(22,7 \%)+ \\
\mathrm{Gd}_{2} \mathrm{O}_{3}(11,4 \%)+ \\
\mathrm{Ce}_{2} \mathrm{O}_{3}(9,1 \%) \\
(22 \mathrm{KBT}, 12.04 .2018) \\
\end{array}$ & $\begin{array}{l}\mathrm{Al}_{2} \mathrm{Y}_{3} \mathrm{O}_{12}-\mathrm{Cubic} \\
\quad \mathrm{Ia}-3 \mathrm{~d}(230)\end{array}$ & $a=11.91594$ & 48.5 & 86.3 & 100 \\
\hline
\end{tabular}

Thus, obtained ceramics is a system of small crystallites, which can be combined into microcrystals up to $50 \mu \mathrm{m}$, has a dominant YAG (or YAGG) phase, the composition is close to the corresponding this phase, but non-stoichiometric.

\section{Photoluminescence when excited by a blue LED}

The synthesized YAG ceramics samples intensively luminesce when excited by radiation of a chip at $460 \mathrm{~nm}$ in the range of 500-700 nm, like a YAG:Ce and YAGG:Ce phosphors [9, 12-14].

Figure $3(a, b)$ shows the results of measuring the luminescence spectra measured when excited the sample splitting surface. The whole area of split well luminesces, however, the brightness distribution over the surface is non-uniform. The luminescence maximum of YAG:Ce ceramics falls on $555 \mathrm{~nm}$, the band half-width is $0.45 \mathrm{eV}$. In YAGG:Ce ceramics, the luminescence maximum at $555 \mathrm{~nm}$, the band half-width is $0.48 \mathrm{eV}$. The shift of the band in YAGG:Ce ceramics relative to the strip in YAG:Ce is a characteristic feature of phosphors containing $\mathrm{Gd}^{3+}$ ions as modifiers. The half-widths of the luminescence bands in the synthesized ceramic samples are within the limits of the corresponding phosphors and ceramics [15] based on YAG:Ce, measured in $[13,16]$. 

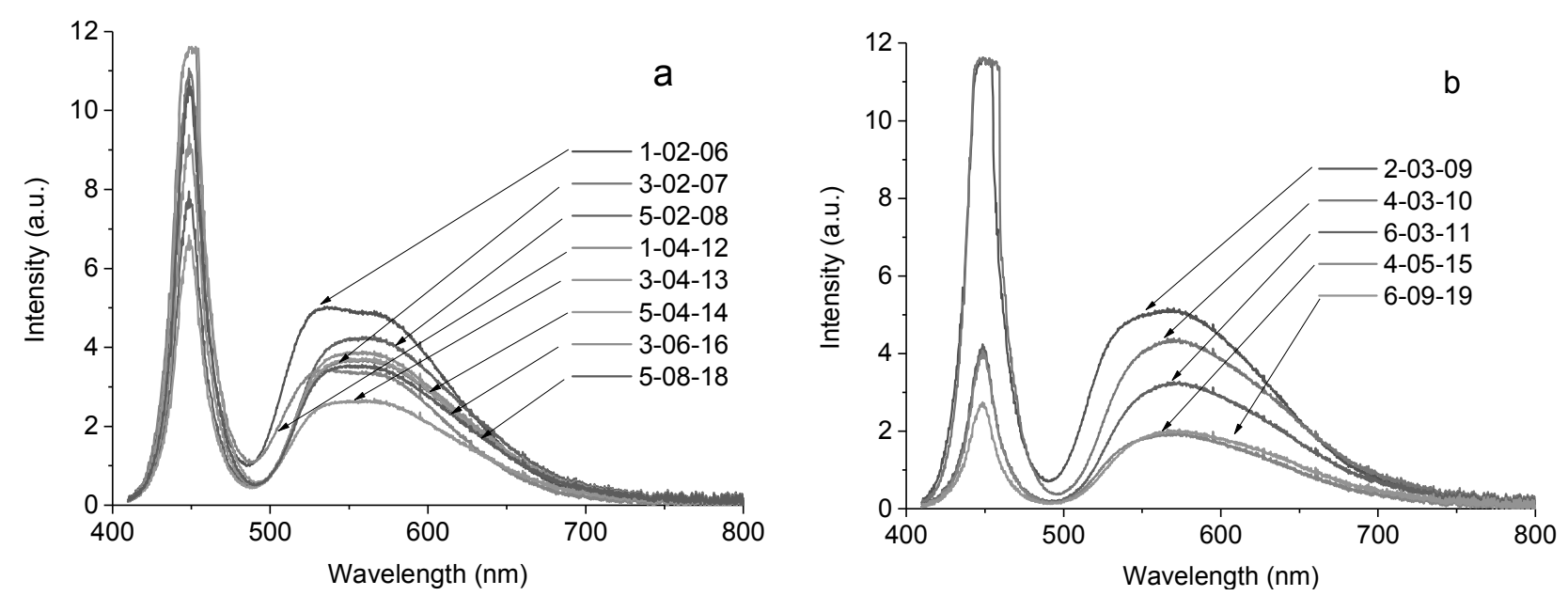

$a-\mathrm{YAG}: \mathrm{Ce} ; b-\mathrm{YAGG}: \mathrm{Ce}$

Figure 3. Luminescence spectra of ceramics when excited at $460 \mathrm{~nm}$

\section{Discussion}

YAG:Ce ceramics first synthesized in the field of powerful flux of radiation. Ceramics has a heterogeneous structure. The main phase of obtained ceramics is YAG, which makes up from 72 to $91 \%$ of the total volume of the samples. The remaining volume of samples consists of phases $\mathrm{Al}_{2} \mathrm{O}_{3}$ and $\mathrm{CeO}_{2}$. Synthesized ceramics has characteristics like a YAG:Ce, YAGG:Cephosphors.

Thus, the synthesis of luminescent YAG:Ce, YAGG:Ce ceramics in a radiation field is possible. The advantages of this method are obvious. The synthesis time is 1 second. The efficiency of synthesis compared to the commonly used thermal is determined by ionization processes, but not by thermal ones. With used irradiation modes, during the exposure to the radiation flux, the charge absorbs $6.10^{23} \mathrm{eV} / \mathrm{cm}^{3}$ in the charge, $\sim 6 \ldots 10^{22} \mathrm{~cm}^{-3}$ electronic excitations (ions, excitons, electron-hole pairs) are creating. Consequently, the formation of structural phases occurs from a set of charge elements with a high degree of ionization, that is, from a state close to the plasma state. This provides good mixing of the elements of the composition, can be obtained ceramics with a composition close to stoichiometric. The radiation field, the distribution of the absorbed energy in the charge can be well controlled. Consequently, synthesis in the radiation field can provide high reproducibility of obtained materials.

\section{References}

1 Kong, D.S., Kim, M.J., Song, H.J., Cho, I.S., Jeong, S., \& Shin, et al. (2016). Fine tuning of emission property of white lightemitting diodes by quantum-dot-coating on YAG:Ce nanophosphors. Appl. Surf. Sci, 379, 467-473.

2 Nakamura, S., Mukai, T., \& Senoh, M. (1994). Candela-class high-brightness InGaN/AlGaN double-heterostructure bluelight-emitting diodes. J. Appl. Phys., 76(8189), 1687-1689.

3 Xia, Z., \& Meijerink, A. (2017). Ce ${ }^{3+}$-Doped garnet phosphors: composition modification, luminescence properties and applications. Chem. Soc. Rev., 46, 275-299.

4 Lee, S., \& Seo, S.Y. (2002). Optimization of yttrium aluminum gamet: $\mathrm{Ce}^{3+}$ phosphors for white light-emitting diodes by combinatorial chemistry method. J. Electrochem. Soc., 149, 85-88.

5 Jacobs, R.R., Krupke, W.F., \& Weber, M.J. (1978). Measurement of excited-state-absorption loss for $\mathrm{Ce}^{3+}$ in $\mathrm{Y}_{3} \mathrm{Al}_{5} \mathrm{O}_{12}$ and implications for tunable $5 \mathrm{~d} \rightarrow 4 \mathrm{f}$ rare-earth lasers. Applied Physics Letters, 33(5), 410-415.

6 Ming, L., Ding, Z., Cui P, \& Li, Zhe Z. (2016). Low temperature molten salt synthesis of YAG:Ce spherical powder and its thermally stable luminescent properties after post-annealing treatment. Materials Science in Semiconductor Processing, 44, $101-107$.

7 Kareiva, A. (2011). Aqueous Sol-Gel Synthesis Methods for the Preparation of Garnet Crystal Structure Compounds. Materials science, 17, 4, 428-437.

8 Fu, Y.-P. (2006). Preparation of $\mathrm{Y}_{3} \mathrm{Al}_{5} \mathrm{O}_{12}$ :Ce powders by microwave induced combustion process and their luminescent properties. J. Alloys Compd., 181-185.

9 Hyun Song, Y., Eun Kyung, J., Byung Woo, J., Mong Kwon, J., Kim, E.Y., \& Lee, C.W., et al. (2017). Design of laserdriven high-efficiency $\mathrm{Al}_{2} \mathrm{O}_{3} / \mathrm{YAG}: \mathrm{Ce}^{3+}$ ceramic converter for automotive lighting: Fabrication, luminous emittance, and tunable color space. Dyes and Pigments, 139, 688-692.

10 Yi-Chen, Ch., \& Yung-Tang, N. (2017). Microstructure and photoluminescence properties of laser sintered YAG:Ce phosphor ceramics. Journal of the European Ceramic Society, 223-227. 
11 Yung-Tang, N., Yi-Chen, Ch., \& I-Chi, Ch. (2018). Microstructure, phase transformation and photoluminescence of YAG:Ce ceramics by $\mathrm{CO}_{2}$ laser sintering. Journal of Alloys and Compounds, 797, 110-116.

12 Zehua, L., \& Shuxing, L., et.al. (2018). Composite ceramic with high saturation input powder in solid-state laser lighting: Microstructure, properties, and luminous emittances. ScienceDirect Ceramics International, 44, 20232-20238.

13 Hongling, S., \& Chen, Z., et al. (2014). Luminescence properties of YAG:Ce, Gd phosphors synthesized under vacuum condition and their white LED performances. Optical Materials Express, 4(4), 649-655.

14 Xianqiang, Ch., Haiming, Q., Ye, Zh., Jun, J., \& Haochuan, J. (2015). Highly transparent $\mathrm{ZrO}_{2}$-doped $\left(\mathrm{Ce}, \mathrm{Gd}_{3} \mathrm{Al}_{3} \mathrm{Ga}_{2} \mathrm{O}_{12}\right.$ ceramics prepared via oxygen sintering. Journal of the European Ceramic Society, 35, 3879-3883.

15 Zehua, L., \& Li, S. et al. (2019). The effect of the porosity on the $\mathrm{Al}_{2} \mathrm{O}_{3}-\mathrm{YAG}$ :Ce phosphor ceramic: Microstructure, luminescent efficiency, and luminous stability in laser-driven lighting. Journal of Alloys and Compounds, 785, 125-130.

16 Dusan, B., \& Krstic, V. (2018). The effect of SiC addition on photoluminescence of YAG:Ce phosphor for white LED. Journal of the European Ceramic Society, 38, 5519-5524.

Ж. Карипбаев, Д. Мусаханов, В. Лисицын, Г. Алпысова, М. Голковский, Л. Лисицына, А. Тулегенова, А. Акылбеков, А. Даулетбекова, К. Балабеков, А. Козловский, А. Усеинов

\title{
Радиация өрісіндегі ИАГ және ИАГГ люминофорларының құрылымын зерттеу және синтездеу
}

\begin{abstract}
Мақалада қатты радиацияның күшті ағындарын пайдаланып, люминофорды синтездеуге әрекет жасалды. Алынған YAG:Се керамиканың беткі құрылымы, элементттік құрамы және люминесценттік қасиеттері зерттелді. Керамика гетерогенді құрылымға ие. Алынған керамиканың негізгі фазасы YAG болып табылады, ол үлгілердің жалпы көлемінің 72-91 \% құрайды. Үлгілердің қалған көлемі $\mathrm{Al}_{2} \mathrm{O}_{3}$ және $\mathrm{CeO}_{2}$ фазаларынан тұрады. Синтезделген керамика YAG:Ce, YAGG:Cе люминофорларының сипаттамаларына тән. Сканерлі электронды микроскоптың көмегімен синтезделген керамика беті мен бетінің күйі зерттелді. Зерттеу нәтижесінде микрокристалдардың пайда болуын көрсететін нақты анықталған бөлшектер бар екендігі көрсетілді. Синтезделген керамикалық үлгілердің рентгендік талдауы дифрактометрде жүргізілді. ТОПАС-4.2 бағдарламасында сандық фаза тәуелділігі анықталды. Үлгілердің беттік бөліну кезіндегі люминесценттік спектрлерінің өлшеу нәтижелері келтірілген. YAG:Cе керамикасының максималды люминесценциясы: 555 нм құрайды, жолақтың жарты ені - 0,45 эB. YAGG:Се керамикасында люминесценцияның максималды мәні 555 нм, жолақтың жарты ені - 0,48 эВ.
\end{abstract}

Кілт сөздер: ақ жарық диодтары, иттрий-алюминий гранат, люминофор, керамика, радиация өрісіндегі синтез.

Ж. Карипбаев, Д. Мусаханов, В. Лисицын, Г. Алпысова, М. Голковский, Л. Лисицына, А. Тулегенова, А. Акылбеков, А. Даулетбекова, К. Балабеков, А. Козловский, А. Усеинов

\section{Синтез, исследование структуры ИАГ и ИАГГ люминофоров в поле радиации}

\begin{abstract}
В статье предпринята попытка синтеза люминофора с использованием мощных потоков жесткой радиации. Проведены исследования поверхности, элементного состава, структуры и люминесцентные характеристики полученной YAG:Cе керамики. Керамика имеет гетерогенную структуру. Основной фазой полученной керамики является ИАГ, которая составляет от 72 до $91 \%$ от всего объема образцов. Остальной объем образцов составляют фазы $\mathrm{Al}_{2} \mathrm{O}_{3}$ и $\mathrm{CeO}_{2}$. Синтезированная керамика имеет характерные для ИАГ:Се, ИАГГ:Се люминофоров свойства. Состояние поверхности и элементный состав поверхности образца синтезированной керамики были изучены с использованием сканирующего электронного микроскопа. Снимки показали, что встречаются частицы с хорошо выраженной огранкой, это свидетельствует о формировании микрокристаллов. Рентгеноструктурный анализ синтезированных образцов керамики проводили на дифрактометре. Рентгеноструктурный анализ показал, что полученная керамика имеет высокую степень кристалличности. Количественная фазовая зависимость определялась в программе TOPAS-4.2. Приведены результаты измерения спектров люминесценции, измеренных при возбуждении поверхности раскола образцов. Максимум люминесценции ИАГ:Се керамики приходится на 555 нм, полуширина полосы равна 0,45 эВ. В ИАГГ:Се керамике максимум люминесценции на 555 нм, полуширина полосы равна 0,48 эВ.
\end{abstract}

Ключевые слова: белые светодиоды, иттрий-алюминиевый гранат, люминофор, керамика, синтез в поле радиации. 